\title{
Shift of LeXical CoHesion in Translation OF THE Novel THE ADVENTURES OF SHERLOCK HOLMES
}

\author{
Ni Nyoman Yuliastari \\ Badung Government Tourism Office \\ astarinyoman1@gmail.com
}

\begin{abstract}
Translation plays an important role in bridging the gaps between different culture and nations. Translation is not an easy process since no two languages have identical linguistic system and culture. The difference of linguistic systems and culture in two languages made the translation cannot be an exact equivalent transferred from the source language into the target language. This paper aims to describe the translation equivalent of the lexical cohesion found in The Adventures of Sherlock Holmes; and to identify the effects of shift of cohesion in translation of The Adventures of Sherlock Holmes and its translation. In this paper qualitative descriptive method is used to describe or analyze the data of shift of cohesion in translation. The finding shows that the lexical cohesion in the text is built by a number of repetitions, synonymy, nearsynonymy, superordinate, general word and collocation. Shifts of cohesion found in the novel are shifts in the level of explicitness and shifts in the textual meaning(s).
\end{abstract}

Keywords: lexical cohesion, translation strategy, and shift of cohesion

\section{INTRODUCTION}

Translation is not an easy process since no two languages have identical linguistic system and culture. Therefore, when the source language and the target language are widely different in structure and cultural background, there cannot be an exact equivalent transferred from the source language into the target language. It means that in the widest sense (including the lexical and connotative meanings) in the target language there is no exact equivalent of any lexical item in the source language. The consequences in translation are that there will be loss of information, addition of information and skewing of information.

Novel is one of literary works. In the novel, there are many utterances or clauses. In every clause, there is a device which makes one clause related to another. The device is named cohesion. Cohesion is a semantic relation, but text is a semantic unit. Cohesion in a text can be analyzed through the linguistic devices which are called the cohesive devices. Lexical cohesion embraces two distinctions though related aspects which are referred to as reiteration and collocation (Halliday \& Hasan, 1976:318).

The reason why this topic is interesting to discuss is that English and Indonesian are markedly different languages. Indonesian is different from English from lexical, structural, grammatical and many other aspects. From the lexical perspective, some words which work as cohesion devices in English may hardly find their counterparts in Indonesia, or they may carry different meanings in certain context. In English grammar is important, while Indonesian may ignore it in some context when it still makes sense. All these differences, in addition to many social, cultural, conventional differences lead to cohesion shift in English-Indonesian translation to raise textual equivalence. They also give challenges in EnglishIndonesian translation.

Due to the difficulties faced in translating English lexical cohesion, there are some problems highlighted in this study. The problems are formulated as follows: what types of lexical cohesion found in the novel The Adventures of Sherlock Holmes and how they are translated into Indonesian? And what are the effects of the shift of lexical cohesion in translation on the target laguage text? The theory applied in finding the answer to the questions above are the theory of cohesion proposed by Halliday and Hasan and the theory of shift of cohesion proposed by by Shosana Blumkulka.

\section{MATERIALS AND METHOD}

The data source of this study is the translation of a novel; the data were taken from a novel written by Sir Arthur Conan Doyle, entitled The Adventure of Sherlock Holmes obtained from https://sherlockholm.es/stories/pdf/a4/1-sided/advs.pdf. It was translated into Indonesian by Albert with the same title. The data were collected by reading the source text and the bilingual text of the Adventure of Sherlock Holmes and its translation thoroughly. All the two versions were read one by one to understand the content and storyline. This study applied the descriptive-qualitative method to analyze the data. To present the result of analysis clearly the English cohesive devices of the source language were compared 
with their translation equivalents in the target language; the English original texts were shown side by side to Indonesian equivalents; the source Language and Target Language were completed with some lines, followed with the analysis.

\section{RESULTS AND DISCUSSION}

There are two categories of lexical cohesion in the translation found in the data. They are lexical cohesion as reiteration, and lexical cohesion as collocation. The lexical cohesion as reiteration is divided into four categories; they are reiteration, synonymy, superordinate and general words. After that, the lexical cohesion found in the source text was compared with the translation in the target text. The translation of cohesive devices was analyzed using the theory of translation proposed by Mona Baker. This answers the first problem of this study. Then, to answer the second problem, the data were analyzed and described based on the shifts occurring in the translation of cohesion.

\subsection{SHIFT IN THE LEVEL OF EXPLICITNESS}

Blum-Kulka (1986:22) stated that when the meaning of TL becomes deeper than SL, connected explicitly as lexically and grammatically, giving the text a dense, close texture as shift of cohesion, meaning that the explicitness occurs in TL.

\subsubsection{THE GENERAL LEVEL OF THE TARGET TEXTUAL EXPLICITNESS IS HIGHER THAN THAT OF THE SOURCE TEXT}

Blum-Kulka pointed that as required by the target language (TL) grammatical system, TL will be repeated once more than source language (SL). The result is that in TL it becomes in the higher level of redundancy compared with SL.

Data (01)

SL: (1) "We were both in the photograph."

(2) "Oh, dear! That is very bad! Your Majesty has indeed committed an indiscretion."

(3) "I was mad-insane."

(4) "You have compromised yourself seriously."

(5) "I was only Crown Prince then. I was young. I am but thirty now." (P. 8)

TL: (1) "Foto kami berdua"

(2) Wah! wah! Yang Mulia telah bertindak sembrono

(3) "waktu itu saya tergila-gila padanya sehingga tak sadar"

(4) “Anda terlibat secara serius'

(5) "Waktu itu saya masih Putra Mahkota. Masih muda sekali. Sekarang saja umur saya belum genap tiga puluh. (P.17)

In data (01), the type of lexical cohesion is superordinate. Superordinate is a word with a general meaning that includes the meanings of other particular words. Based on the data above, there is a relation between the word 'crown prince' with the word 'young' and 'thirty'. The word 'young' is superordinate of the words 'thirty' and 'crown prince'. 'young' is the general class of 'thirty' the age of the 'crown prince' when he became heir to the throne.

SL: "I was only Crown Prince then. I was Young

TL: "Waktu itu saya masih Putra Mahkota. Masih muda sekali

The general level of explicitness which is higher than SL occurs in the sentence above, because in literal meaning I was young is equivalent to saya muda. The translator added the word 'sekali' for the naturalness of style and it explains clearly the expression of the source language as an overt meaning (cohesion shift) (Larson 1998:495). In the TL the translator clarifies the SL by adding the word 'sekali' to the TL to emphasize the meaning. The translator used this strategy to maintain the cohesiveness of the idea in the following sentence: 'I am but thirty now' which is translated into 'sekarang saja umur saya belum genap tiga puluh' which means that he is feeling old now when he was looking back in the past; therefore, gain of information occurs in this translation. 


\subsubsection{THE GENERAL LEVEL OF THE TARGET TEXTUAL EXPLICITNESS IS LOWER THAN THAT OF THE SOURCE TEXT}

In some cases, the textual level of explicitness is absent due to grammar, semantics, and style of two different forms of languages. The result is in TL it becomes in the lower level of redundancy compared with SL.

Data (02)

SL: (1) "I have spent the whole day," said he, "over Lloyd's registers and files of the old papers,

following the future career of every vessel which touched at Pondicherry in January and February in '83.

(2) There were thirty-six ships of fair tonnage which were reported there during those months.

TL: (1) "Sepanjang hari tadi." Sahutnya, "aku memeriksa daftar pelayaran dan berkas-berkas tua, termasuk semua kapal yang pernah berlabuh di pondicherry pada bulan januari dan pebruari 1883. (2)

Ada tiga puluh enam kapal yang tercatat selama dua bulan itu (p.176).

Based on the data (02), the type of cohesive device in the text is superordinate. Superordinate is the name for a more general class. The expression 'thirty -six ships' refers to the phrase 'every vessel', because the word 'vessel' is a general term that describes a watercraft. A ship is a type of vessel. Much like boats, however, we would describe a boat as a smaller vessel, and a ship would be a larger vessel, like cargo ships that carry goods. You could transport a boat on a ship, but you could not transport a ship on a boat. Both would be described as vessels. The translation strategy that the translator used to translate is the translation strategy of using a more general word (superordinate). The word 'vessel' in SL is translated into 'kapal' in TL because both words have the same conceptual meaning. The word 'vessel' means a ship or large boat, meanwhile, the word 'kapal' in TL means a vessel which is larger than a boat used for transporting people or goods by sea.

The effect of the translation shift of lexical cohesion in translation is the general level of the Target textual explicitness is lower than that of the source text, because the phrase 'every vessel' in the source language is translated into 'semua kapal' in TL. Both 'vessel' and 'ship' share the same conceptual meaning; water transportation. There is also a slight difference; it can be distinguished by its size and function between ship, boat, yacht, or even a dinghy.

\subsection{ShIFT IN TEXT MEANING}

\subsubsection{The Explicit Meaning in the SL Potentially Changes into Implicit through TRANSLATION}

English has specific grammatical markers which are cohesively obligatory. In English, $a$ is an indefinite obligatory article to make explicit meaning whether a noun is singular or plural as in the example below:

\section{Data (03)}

SL: (1) Looking over his shoulder, I saw that on the pavement opposite there stood a large woman with a heavy fur boa round her neck, and a large curling red feather in a broad-brimmed hat which was tilted in a coquettish Duchess of Devonshire fashion over her ear. (p.31)

TL: (1) Dari belakang bahunya, aku melihat seorang wanita tinggi besar berdiri di trotoar seberang. (2) Lehernya tertutup syal bulu binatang, dan ia mengenakan topi lebar yang tepat seperti gaya Duchess of Devonshire yang genit. (p.82)

The type of lexical cohesion in the data above is collocation. It can be seen from the pattern in the data above about fashion things. The paragraph is semantically related to fashion things such as 'fur', 'red feather', and ' $h a t$ '. This collocation in fashion terms supports the idea in the whole paragraph about the woman figure or characteristic that has been mentioned in the previous sentence. The translation strategy that the translator used paraphrasing using a related word. It can be seen in the first sentence that a heavy fur boa in SL is translated into syal bulu binatang in TL in second sentence literally, the translation of a heavy fur boa is sebuah syal bulu-bulu yang berat, but it is translated into syal bulu binatang, because boa itself means a long thin stole of feathers or fur worn around a woman's neck, typically as part of evening dress. The literary translation is too much redundant, so the translator used syal bulu binatang because it sounds natural. In the data above, it can be seen that in the source language, the indefinite article ' $a$ ' in 'a heavy fur boa', 'a large curling red feather',' a broad brimmed hat', and 'a coquettish Duchess of Devonshire' is used before the countable or singular nouns referring to things and people. The indefinite article ' $a$ ' in ' $a$ heavy fur boa' means one heavy fur boa. And it has the same meaning as 'a large curling red feather' and 'a broad brimmed hat'. On the other hand, the use 
of the indefinite article ' $a$ ' in ' $a$ coquettish Duchess of Devonshire' refers to a person. Therefore, when it is used to refer to a human in the target language, it can be 'seperti gaya seorang Duchess of Devonshire yang genit'.

The effect of translation is the explicit meaning in the SL potentially changes into implicit through translation, because the absence of the indefinite grammatical feature ' $a$ ' in the target language means that the referential meaning of 'syal bulu', 'topi lebar' and 'Duchess' is left implicit.

\subsubsection{THE IMPLICIT MEANING OF SL POTENTIALLY CHANGES INTO EXPLICIT THROUGH TRANSLATION}

The cultural background of SL may cause the implicit meaning to change into explicit meaning of TL. The different grammatical structure of SL may require TL to be made explicit (Larson 1998:494).

(Data 04)

SL: (1) "The goose, Mr. Holmes! (2) The goose, sir!" he gasped.

TL: (1) "Bebek itu, Mr Holmes! (2) Bebek itu!” katanya dengan terengah-engah. (p.225)

In data above the types of lexical cohesion are repetition and superordinate. Repetition means the word 'goose' in the second sentence refers to the word 'goose' in the first sentence. Superordinate is a name for more general class. It is used to refer to a word which has general properties rather than specific ones. "Sir" refers back to Mr. Holmes; and "Sir" is a superordinate of Mr Holmes - that is a name of the general class. The translation strategy that the translator used is cultural substitution. This strategy involves replacing a culture-specific item or expression with a target language item which does not have the same propositional meaning but it is likely to have a similar impact on the target reader. The main advantage of using this strategy is that it gives the reader a concept with which the reader can identify something familiar and appealing. It can be seen in the word 'goose' in the first and second sentences. Literally, the word 'goose' in SL means a large waterbird with a long neck, short legs, webbed feet, and a short broad bill. In the TL the word 'goose' is translated into the word 'bebek'. The word 'bebek' in TL is literally translated into 'duck' which means a waterbird with a broad blunt bill, short legs, webbed feet, and a waddling gait. The translator decided to use the word 'bebek' in TL rather than 'angsa', because the concept of the word bebek is more familiar and easier to be identified to the reader. As we know in the reader's culture that 'bebek' is a waterbird that can be more commonly consumed rather than angsa. In the next sentence, the translation strategy that the translation used is ommision. It can be seen from the word 'sir' in the SL which is missing in the TL because such an expression is more common in TL. Therefore, we know that the loss of information occurs in this translation in which the determiner in SL disappears which can actually be translated into 'itu' in the target language.

Although there is loss of information in the second sentence in TL, the implicit meaning in SL potentially changes into explicit meaning in TL through translation, because the word 'bebek' in TL is made to be more explicit through translation.

\section{CONCLUSION}

According to the discussions, it can be concluded that lexical cohesion in the text are built through a number of repetition and superordinate. The strategy that the translator used to translate lexical cohesion in data are more general word (superordinate), translation by a more neutral/less expressive word, translation by cultural substitution, and Translation by ommision. The effect of the translation found in the data are the general level of the target text's textual explicitness is higher than that of the source text, the general level of the target text's textual explicitness is lower than that of the source text. The explicit meaning potensial of the source language changes into implicit through translation, and the implicit meaning potensial of the source language changes into explicit through translation.

\section{REFERENCES}

Bassnett, Susan. 1991. Translation Studies. London: Routledge

Bell, R.T. 1991. Translation and Translating: Theory and Practice. London: Longman

Brata, Frans I Made. 2011. Cohesion and Coherence Shift of Expression in Translation. Denpasar: Cakra Press

Blum-Kulka, Shosana. 2000. Shifts of cohesion and coherence in Translation. In the Translation Studies Reader. 298-313. London and New York: Routledge.

Brislin, Richard W. 1976. Translation Applications and Research. New York: Gardner Press, Inc 
Creswell, John W. 2009. Research Design Qualitative, Quantitative and Mixed Methods Approaches. Los Angeles: Sage Publication, Inc.

Doyle, Sir Conan Arthur. The Adventure of Sherlock Holmes. (cited 2017, feb 10) Available https://sherlock-holm.es/stories/pdf/a4/1-sided/advs.pdf

Hornby, Mary Snell et al. 1992. Translation Studies: An Interdiscipline. Philadelphia: John Benjamin Publishing Company

Larson, Mildred.L. 1997. Meaning - Based Translation. Maryland: University Press of America.

Newmark, Peter. 1988. A Textbook of Translation. Hertfordshire: Prentice Hall International (UK) Ltd

Nida, Eugene A \& Charles R. Taber. 1974. The Theory and Practice of Translation. Leiden: E.J. Brill

Nida, Eugene A. 1975. Language Structure and Translation. California: Stanford University Press

Pym, Anthony. 2010. Exploring Translation Theories. London: Routledge

Venuti, Lawrence. 2000. The Translation Studies Reader. London: Routledge 
